\title{
Myeloblast Count
}

National Cancer Institute

\section{Source}

National Cancer Institute. Myeloblast Count. NCI Thesaurus. Code C74632.

The determination of the number of myeloblast cells present in a sample. 